\title{
Hubungan Status Gizi dengan Usia Kejang Demam Pertama pada Anak
}

\author{
Ririn Intania, Herlina Dimiati, Azwar Ridwan \\ Bagian Ilmu Kesehatan Anak Fakultas Kedokteran Universitas Syiah Kuala/RSUD Dr. Zainoel Abidin, Banda Aceh
}

Latar belakang. Demam pada kejang demam dapat disebabkan oleh proses infeksi yang dimungkinkan terjadi akibat malnutrisi pada balita dan digambarkan dalam penilaian status gizi.

Tujuan. Mengetahui hubungan status gizi dengan usia kejang demam pertama pada anak.

Metode. Penelitian analitik cross-sectional dengan pendekatan retrospektif menggunakan data sekunder rekam medis pasien rawat inap kejang demam anak periode Januari - Desember 2019 di RSUD Prof. Dr. M. A. Hanafiah SM, Batusangkar, Sumatera Barat. Sampel penelitian terdiri atas 95 anak dengan kejang demam pertama yang dipilih dengan teknik consecutive sampling. Penelitian dilaksanakan pada 07 sampai dengan 21 November 2020. Pengolahan data menggunakan analisis univariat, bivariat dengan uji korelasi Spearman.

Hasil. Anak dengan kejang demam pertama memiliki gizi baik (50,5\% berdasarkan indeks IMT/U dan 51,6\% berdasarkan indeks BB/PB atau $\mathrm{BB} / \mathrm{TB}$ ), dan berada dalam kelompok umur batita (12 bulan $\leq$ usia kejang demam pertama <36 bulan) dengan rata - rata usia kejang demam pertama 24,42 bulan. Uji Spearman menunjukkan tidak terdapat hubungan yang signifikan antara status gizi dengan usia kejang demam pertama baik berdasarkan indeks IMT/U ( $p=0,260)$ maupun berdasarkan indeks BB/PB atau BB/TB $(p=0,386)$.

Kesimpulan. Tidak terdapat hubungan yang bermakna antara status gizi dengan usia kejang demam pertama pada anak. Sari Pediatri 2021;23(1):28-35

Kata kunci: kejang demam, status gizi, usia kejang demam pertama

\section{Relationship between Nutritional Status and Age of First Febrile Convulsion in Children}

Ririn Intania, Herlina Dimiati, Azwar Ridwan

Background. Fever in febrile convulsion may be caused by the process of infection that is likely lead by malnutrition, which can be seen in nutritional status assessment.

Objective. To find out the relationship between nutritional status and age of first febrile convulsion in children.

Methods. This study used a cross-sectional design with a retrospective approach based on secondary data of pediatric febrile convulsion inpatient's history during January to December 2019 period from Regional General Hospital Prof. Dr. M. A. Hanafiah SM Batusangkar, West Sumatra. The samples of this study were 95 children with first febrile convulsion who were selected through consecutive sampling techniques. This study was conducted from November $7^{\text {th }}$ to November $21^{\text {st }}, 2020$. This study used univariate and bivariate analysis using Spearman correlation test.

Result. Children with first febrile convulsion had good nutrition (50,5\% according to BMI for age and 51,6\% according to weight for length or weight for height index) and were in the toddler age group (12 months $\leq$ age $<36$ months old) with an average of 24.42 months old age. Spearman's test showed that there was no significant relationship between nutritional status and age of first febrile convulsion, based on both the BMI for age ( $\mathrm{p}=0.260)$ and the weight for length or weight for height index $(\mathrm{p}=0.386)$.

Conclusion. In conclusion, there is no significant relationship between nutritional status and the age of first febrile convulsion in children. Sari Pediatri 2021;23(1):28-35

Keywords: febrile convulsion, nutritional status, age of first febrile seizure

Alamat korespondensi: Herlina Dimiati, Ririn Intania. RSUD Dr. Zainoel Abidin. Jl. Tgk Daud Beureueh, Banda Aceh, Aceh. Email: herlinadimiati@unsyiah.ac.id, ririnintania10@gmail.com. 
$\mathrm{K}$

ejang demam merupakan tantangan utama dalam praktik kedokteran anak karena tingkat insiden yang tinggi pada anak bulan, kecenderungannya untuk kembali terjadi, dan merupakan momok bagi orang tua sehingga dapat berdampak pada kualitas hidup keluarga. ${ }^{1-3}$ Vebriasa $\mathrm{dkk}^{4}$ pada tahun 2013 menyimpulkan bahwa kejang demam pertama pada anak yang memiliki riwayat kejang keluarga cenderung terjadi pada usia lebih dini dibandingkan dengan yang tidak memiliki riwayat. Kejang demam sederhana biasanya bersifat tidak berbahaya, tetapi anak dengan kejang demam kompleks berada pada risiko untuk mengalami epilepsi di masa depan. ${ }^{2}$ Etiologi kejang demam masih belum dapat dipastikan sehingga hanya dapat dinilai dari berbagai faktor risiko, yaitu keterlambatan perkembangan, riwayat kejang demam pada keluarga, dan adanya defisiensi zat besi dan zinc. ${ }^{5}$

Fredlina $\mathrm{dkk}^{6}$ pada tahun 2018 memaparkan salah satu masalah utama pemerintah Indonesia untuk anak balita adalah status gizi buruk yang berdampak tingginya prevalensi anemia pada balita. Gangguan gizi dan kesehatan rentan terjadi pada anak usia kurang 5 tahun. ${ }^{7}$ Hasil Riskesdas tahun $2018^{8}$, menunjukkan peringkat provinsi Sumatera Barat berada di atas rata - rata seluruh provinsi di Indonesia untuk status gizi buruk dan gizi kurang pada balita. Status gizi merupakan salah satu faktor yang memengaruhi perkembangan seorang anak. Penggunaan metode penilaian status gizi yang paling sering berupa antropometri gizi berdasarkan nilai ukuran dimensi dan komposisi tubuh (berat badan, tinggi badan, lingkar lengan atas, dan tebal lemak bawah kulit). ${ }^{9,10}$

Hairunis $\mathrm{dkk}^{11}$ tahun 2018 menjelaskan terdapat hubungan yang signifikan antara status gizi dengan perkembangan anak. Perkembangan yang terhambat dan tidak optimal berdasarkan usianya, rentan terjadi pada anak dengan status gizi kurang. ${ }^{11}$ Anak akan rentan terhadap infeksi apabila kebutuhan gizinya tidak terpenuhi. ${ }^{11}$ Kejang demam dapat dipresipitasi oleh infeksi virus terutama pada infeksi saluran pernapasan atas, bakteri, dan pasca vaksinasi. ${ }^{12}$ Infeksi saluran pernapasan akut, otitis media, pneumonia, gastroenteritis, infeksi saluran kemih merupakan penyebab infeksi tersering yang menyebabkan demam pada kasus kejang demam. ${ }^{5}$ Kakalang $\mathrm{dkk}^{13}$ pada tahun 2016 mendapatkan 67,3\% distribusi kejang demam terjadi pada anak dengan status gizi normal. Hasil berbeda ditunjukkan oleh Hussain $\mathrm{dkk}^{14}$ pada tahun 2015 dengan 64\% distribusi kejang demam merupakan anak dengan malnutrisi.

Adanya perbedaan hasil penelitian terkait asosiasi status gizi dan infeksi bakteri terhadap kejang demam sehingga diperlukan studi lebih lanjut untuk menilai keterkaitannya. ${ }^{14}$ Seorang anak rentan terhadap kekurangan asupan gizi maupun mengalami kejang demam terjadi pada usia krusial tumbuh kembang anak yang sama, yaitu usia 6-60 bulan. ${ }^{15}$

Oleh karena adanya kesamaan usia anak yang rentan terkena kejang demam dan mengalami permasalahan gizi yang dinilai melalui indikator status gizi, tidak spesifiknya etiologi dari kejang demam, serta kurangnya penelitian terkait status gizi dan keterkaitannya terhadap anak kejang demam lebih lanjut terhadap usia kejang demam pertama, penulis tertarik untuk meneliti tentang hubungan status gizi dengan usia pertama kejang demam pada anak. Tulisan ini dibuat untuk mengetahui hubungan status gizi dengan usia kejang demam pertama pada anak.

\section{Metode}

Jenis penelitian ini adalah analitik observasional cross sectional dengan pendekatan retrospektif. Digunakan data sekunder rekam medis pasien rawat inap kejang demam anak periode Januari - Desember 2019. Penelitian dilaksanakan pada 07 sampai dengan 21 November 2020. Populasi penelitian adalah pasien rawat inap kejang demam anak periode Januari Desember 2019 di RSUD Prof. Dr. M. A. Hanafiah SM Batusangkar, Sumatera Barat. Sampel penelitian adalah populasi yang memenuhi kriteria inklusi. Pengambilan sampel dilakukan dengan teknik consecutive sampling. Kriteria inklusi adalah anak dengan kejang demam, baik sederhana maupun kompleks; berusia 6-60 bulan ketika terjadi kejang demam pertama; tercatat sebagai pasien rawat inap di RSUD Prof. Dr. M. A. Hanafiah SM Batusangkar; memiliki kelengkapan data rekam medis. Kelengkapan data tersebutmencakup jenis kelamin, usia kejang demam pertama, berat badan, panjang/tinggi badan. Kriteria eksklusi adalah anak yang memiliki salah satu atau lebih kondisi epilepsi, kejang tanpa demam, riwayat gangguan neurologis/neurodevelopmental sebelum kejang demam pertama, dan infeksi sistem saraf pusat. Penelitian ini telah mendapatkan persetujuan etik 
dari Komite Etik Fakultas Kedokteran Universitas Syiah Kuala dengan nomor 244/EA/FK-RSUDZA/2020.

Data antropometri untuk penilaian status gizi anak diolah dengan menggunakan perangkat lunak WHO Anthro ${ }^{\oplus}$ untuk mendapatkan nilai $z$-score. Nilai $z$-score selanjutnya berperan dalam menentukan kategori status gizi anak. Penggolongan status gizi berpedoman pada tabel indeks antropometri Permenkes No. 2 tahun 2020. Penilaian status gizi anak ditentukan berdasarkan nilai z-score indeks IMT/U dan BB/PB atau BB/TB pada anak usia 0-24 bulan dan usia 24-60 bulan sesuai dengan jenis kelamin anak.

Data penelitian yang diambil kemudian dimasukkan ke dalam program perangkat lunak SPSS ${ }^{\circledR} 22$ untuk dilakukan uji analisis univariat dan bivariat.

\section{Hasil}

Penelitian ini dilaksanakan di unit rekam medis RSUD Prof. Dr. M. A. Hanafiah SM Batusangkar, Sumatera Barat pada 07 sampai dengan 21 November 2020. Sampel penelitian adalah 95 anak yang memenuhi kriteria inklusi. Karakteristik sampel dari penelitian ini tertera pada Tabel 1. Karakteristik umum sampel dikelompokkan berdasarkan jenis kelamin, kelompok usia, klasifikasi kejang demam, riwayat kejang demam keluarga, dan kondisi penyakit yang menyertai kejang demam.

Tabel 1 menunjukkan sebagian besar berjenis kelamin laki - laki dengan jumlah 65 (68,4 \%), dan sisanya adalah 30 perempuan $(31,6 \%)$. Usia kejang demam pertama sebagian besar berada pada kelompok usia batita ( $12 \leq$ usia <36 bulan) sebanyak 57,9\%, diikuti kelompok pra sekolah 23,2\%, dan kelompok bayi (<12 bulan) $18,9 \%$. Klasifikasi kejang demam mendapatkan $66(69,5 \%)$ mengalami kejang demam sederhana dan $29(30,5 \%)$ mengalami kejang demam kompleks. Kategori riwayat kejang demam pada keluarga didapatkan 60 (63,2\%) tidak memiliki riwayat dan $35(36,8 \%)$ memiliki riwayat kejang demam pada keluarga. Sebagian besar infeksi yang menyertai anak dengan kejang demam adalah infeksi saluran napas atas dengan jumlah $62(65,3 \%)$ kasus, $14(14,7 \%)$ gastroenteritis akut, $12(12,6 \%)$ infeksi saluran napas bawah, $3(3,1 \%)$ demam tifoid, $2(2,1 \%)$ infeksi saluran kemih, $1(1,1 \%)$ Sindrom Steven Johnson, dan serta 1 $(1,1 \%)$ kasus morbili.
Tabel 1. Karakteristik sampel

\begin{tabular}{|c|c|c|}
\hline Karakteristik sampel & $\begin{array}{l}\text { Frekuensi } \\
\text { (n) }\end{array}$ & $\begin{array}{c}\text { Persentase } \\
(\%)\end{array}$ \\
\hline \multicolumn{3}{|l|}{ Jenis kelamin } \\
\hline Laki-laki & 65 & 68,4 \\
\hline Perempuan & 30 & 31,6 \\
\hline \multicolumn{3}{|l|}{ Usia kejang demam pertama } \\
\hline Bayi (<12 bulan) & 18 & 18,9 \\
\hline Batita $(12 \leq$ usia< $<36$ bulan $)$ & 55 & 57,9 \\
\hline Pra sekolah ( $36 \leq$ usia $\leq 60$ bulan $)$ & 22 & 23,2 \\
\hline \multicolumn{3}{|l|}{ Klasifikasi kejang demam } \\
\hline Sederhana & 66 & 69,5 \\
\hline Kompleks & 29 & 30,5 \\
\hline \multicolumn{3}{|l|}{ Riwayat kejang demam keluarga } \\
\hline Tidak ada & 60 & 63,2 \\
\hline Ada & 35 & 36,8 \\
\hline \multicolumn{3}{|c|}{ Kondisi penyakit yang menyertai kejang demam } \\
\hline Infeksi saluran napas atas & 62 & 65,3 \\
\hline Infeksi saluran napas bawah & 12 & 12,6 \\
\hline Gastroenteritis akut & 14 & 14,7 \\
\hline Infeksi saluran kemih & 2 & 2,1 \\
\hline Demam tifoid & 3 & 3,1 \\
\hline Morbili & 1 & 1,1 \\
\hline Sindrom Steven Johnson & 1 & 1,1 \\
\hline
\end{tabular}

Penilaian status gizi balita ditentukan sesuai dengan Permenkes No. 2 Tahun 2020 berdasarkan indeks IMT/U dan indeks BB/PB atau BB/TB tertera pada Tabel 2 dan 3. Data tinggi badan, berat badan, dan usia dalam bulan penuh diolah dengan menggunakan aplikasi WHO Anthro untuk mendapatkan nilai $z$-score dan status gizi diinterpretasikan sesuai dengan Permenkes No. 2 Tahun 2020 berdasarkan indeks IMT/U dan indeks BB/PB atau BB/TB menggunakan formula pada Microsoft Excel.

Berdasarkan indeks IMT/U pada Tabel 2, didapatkan $48(50,5 \%)$ sampel dengan gizi baik, $32(33,7 \%)$ gizi kurang, $7(7,4 \%)$ berisiko gizi lebih, $4(4,2 \%)$ gizi lebih, 4 (4,2\%) gizi buruk, dan tidak ditemukan sampel dengan obesitas.

Berdasarkan indeks BB/PB atau BB/TB pada Tabel 3, didapatkan 49 (51,6\%) sampel dengan gizi baik, 32 (33,7 \%) gizi kurang, $9(9,5 \%)$ berisiko gizi lebih, 3 (3,2 \%) gizi buruk, 2 (2,0 \%) gizi lebih, dan tidak ditemukan sampel dengan obesitas. 
Ririn Intania dkk: Hubungan status gizi dengan usia kejang demam pertama

Tabel 2. Gambaran status gizi berdasarkan IMT/U

\begin{tabular}{lcc}
\hline Status gizi IMT/U & Frekuensi (n) & $\%$ \\
\hline Gizi buruk & 4 & 4,2 \\
Gizi kurang & 32 & 33,7 \\
Gizi baik & 48 & 50,5 \\
Berisiko gizi lebih & 7 & 7,4 \\
Gizi lebih & 4 & 4,2 \\
Obesitas & 0 & 0,0 \\
\hline Total & 95 & 100 \\
\hline
\end{tabular}

Tabel 3. Gambaran status gizi berdasarkan indeks $\mathrm{BB} / \mathrm{PB}$ atau $\mathrm{BB} / \mathrm{TB}$

\begin{tabular}{lcc}
\hline Status gizi BB/PB atau & Frekuensi (n) & $\%$ \\
BB/TB & & \\
\hline Gizi buruk & 3 & 3,2 \\
Gizi kurang & 32 & 33,7 \\
Gizi baik & 49 & 51,6 \\
Berisiko gizi lebih & 9 & 9,5 \\
Gizi lebih & 2 & 2,0 \\
Obesitas & 0 & 0,0 \\
\hline Total & 95 & 100 \\
\hline
\end{tabular}

Secara umum, hasil penilaian status gizi berdasarkan indeks IMT/U memiliki kesamaan dengan indeks $\mathrm{BB} / \mathrm{PB}$ atau $\mathrm{BB} / \mathrm{PB}$, kecuali terdapat perbedaan pada beberapa penggolongan kategori status gizi anak yang mencakup terdapat 1 anak termasuk kategori kondisi status gizi buruk berdasarkan indeks IMT/U, tetapi tergolong gizi kurang berdasarkan indeks $\mathrm{BB} /$ $\mathrm{PB}$ atau $\mathrm{BB} / \mathrm{TB}$; 1 anak termasuk status gizi kurang berdasarkan indeks IMT/U, tetapi tergolong status gizi baik berdasarkan indeks $\mathrm{BB} / \mathrm{PB}$ atau $\mathrm{BB} / \mathrm{TB}$; 1 anak termasuk berisiko gizi lebih berdasarkan indeks IMT/U, tetapi tergolong status gizi baik berdasarkan indeks $\mathrm{BB} /$ $\mathrm{PB}$ atau $\mathrm{BB} / \mathrm{TB}$; serta terdapat 2 anak dengan status gizi lebih berdasarkan indeks IMT/U, tetapi termasuk berisiko gizi lebih berdasarkan indeks $\mathrm{BB} / \mathrm{PB}$ atau $\mathrm{BB} / \mathrm{TB}$. Perbedaan ini dimungkinkan karena tingkat sensitivitas masing-masing indeks yang berbeda. Indeks IMT/U lebih sensitif untuk penilaian anak dengan gizi lebih dan obesitas, sementara indeks BB/PB atau BB/ TB sensitif untuk identifikasi anak dengan gizi kurang, gizi buruk, dan risiko gizi lebih. ${ }^{16}$

Variabel penelitian adalah status gizi (variabel independen) dan usia kejang demam pertama (variabel dependen). Uji korelasi yang digunakan adalah uji korelasi Spearman. Hasil uji statistik hubungan status gizi terhadap usia kejang demam pertama pada anak
Tabel 4. Hubungan status gizi berdasarkan indeks IMT/U dengan usia kejang demam pertama pada anak

\begin{tabular}{|c|c|c|c|c|c|}
\hline \multirow{2}{*}{$\begin{array}{l}\text { Status gizi } \\
\text { IMT/U }\end{array}$} & \multicolumn{2}{|c|}{$\begin{array}{c}\text { Usia kejang } \\
\text { demam pertama }\end{array}$} & \multirow{2}{*}{$\begin{array}{c}\text { Total } \\
\text { Anak pra } \\
\text { sekolah }\end{array}$} & & \multirow[t]{2}{*}{$\mathrm{p}$} \\
\hline & Bayi & Batita & & & \\
\hline Gizi buruk & 0 & 3 & 1 & 4 & \\
\hline Gizi kurang & 5 & 24 & 3 & 32 & \\
\hline Gizi baik & 11 & 24 & 13 & 48 & \\
\hline $\begin{array}{l}\text { Berisiko gizi } \\
\text { lebih }\end{array}$ & 2 & 3 & 2 & 7 & 0,260 \\
\hline Gizi lebih & 0 & 1 & 3 & 4 & \\
\hline Obesitas & 0 & 0 & 0 & 0 & \\
\hline Total & 18 & 55 & 22 & 95 & \\
\hline
\end{tabular}

Tabel 5. Hubungan status gizi berdasarkan indeks $\mathrm{BB} / \mathrm{PB}$ atau $\mathrm{BB} / \mathrm{TB}$

\begin{tabular}{lccccc}
\hline & \multicolumn{7}{c}{ Usia kejang } \\
Status gizi BB/ & demam pertama & Total & & $\mathrm{p}$ \\
\cline { 2 - 7 } PB atau BB/TB & Bayi & Batita & $\begin{array}{c}\text { Anak pra } \\
\text { sekolah }\end{array}$ & & \\
\hline Gizi buruk & 0 & 2 & 1 & 3 & \\
Gizi kurang & 4 & 25 & 3 & 32 & \\
Gizi baik & 12 & 24 & 13 & 49 & \\
Berisiko gizi & 2 & 4 & 3 & 9 & 0,386 \\
lebih & 0 & 0 & 2 & 2 & \\
Gizi lebih & 0 & 0 & 0 & 0 & \\
Obesitas & 18 & 55 & 22 & 95 & \\
\hline Total & & & & & \\
\hline & & & & &
\end{tabular}

tertera pada Tabel 4 untuk penilaian berdasarkan indeks IMT/U dan Tabel 5 untuk penilaian berdasarkan indeks $\mathrm{BB} / \mathrm{PB}$ atau $\mathrm{BB} / \mathrm{TB}$.

Berdasarkan uji korelasi Spearman yang dilakukan terhadap status gizi berdasarkan indeks IMT/U dengan usia kejang demam pertama didapatkan nilai $\mathrm{p}=0,260$ ( $p>\alpha ; \alpha=0,05)$. Dengan demikian dapat disimpulkan bahwa tidak terdapat hubungan antara status gizi berdasarkan indeks IMT/U terhadap usia kejang demam pertama pada anak sesuai tabel. Berdasarkan uji korelasi Spearman yang dilakukan terhadap status gizi berdasarkan indeks $\mathrm{BB} / \mathrm{PB}$ atau $\mathrm{BB} / \mathrm{TB}$ dengan usia kejang demam pertama didapatkan nilai $\mathrm{p}=0,386$ ( $>\alpha ; \alpha=0,05$ ), sehingga dapat disimpulkan bahwa tidak terdapat hubungan antara status gizi berdasarkan indeks $\mathrm{BB} / \mathrm{PB}$ atau $\mathrm{BB} / \mathrm{TB}$ terhadap usia kejang demam pertama pada anak sesuai tabel. 


\section{Pembahasan}

Sebagian besar sampel penelitian ini merupakan anak laki-laki $(68,4 \%)$. Hal ini sejalan dengan penelitian oleh Kakalang $\mathrm{dkk}^{13}$ pada tahun 2016 di RSUP Prof. Dr. R. D. Kandou Manado, yang mendapatkan 66\% kasus anak kejang demam merupakan laki-laki.

Selain itu, penelitian oleh Presto $\mathrm{dkk}^{17}$ pada tahun 2020 menunjukkan rata-rata ukuran foramen parietal pada anak laki-laki cenderung lebih sempit dibandingkan dengan anak perempuan. Hal ini dimungkinkan disebabkan adanya dimorfisme seksual pada anak laki-laki pada proses osifikasi parietal yang menyebabkan ukuran foramen parietalnya lebih sempit dibandingkan anak perempuan. ${ }^{17}$ Keterkaitan ukuran foramen dengan kejadian kejang demam dinilai dari ukuran foramen parietal yang sempit memengaruhi drainase vena otak. ${ }^{17}$ Foramen parietal dan kanalis kondilaris berperan sebagai tempat lewat vena emissaria parietal dan vena emissaria oksipital. ${ }^{17}$ Vena emissaria memiliki katup yang sedikit sehingga memungkinkan peranan penting mereka dalam mekanisme pendinginan otak selektif melalui aliran dua arah dari permukaan evaporasi pada kepala. ${ }^{17}$ Adanya apertura kranium yang sempit menyebabkan aliran ke luar vena serebral berkurang sehingga mekanisme pendinginan otak menjadi tertunda. Kondisi ini memungkinkan demam untuk bertahan dan dapat menyebabkan terjadinya kejang demam pada anak. ${ }^{17}$

Berdasarkan distribusi menurut kelompok umur, didapatkan 55 (57,9\%) sampel yang mengalami kejang demam berada pada kelompok usia batita, 22 (23,2 \%) berada pada kelompok usia anak pra sekolah, dan $18(18,9 \%)$ berada pada kelompok usia bayi sehingga dapat disimpulkan mayoritas usia kejang demam pertama terjadi pada rentang usia batita (12 bulan $\leq$ usia $<36$ bulan). Hal ini didukung oleh penelitian yang dilakukan oleh Saheb dkk ${ }^{18}$ yang menyatakan bahwa kejadian infeksi lebih sering terjadi pada kelompok umur 13-24 bulan karena aktivitas imunologi yang belum matang. Peningkatan kejadian infeksi cenderung meningkatkan kejadian demam. Apabila hal ini tidak tertangani dengan baik, akibat aktivitas imunologi yang belum matang, dapat menimbulkan kejang demam. Demam merupakan respon tubuh yang normal terhadap infeksi. Pelepasan sitokin dalam jumlah banyak selama demam dapat mengubah aktivitas otak normal sehingga dapat memicu terjadinya kejang. ${ }^{19}$ Seiring dengan pertambahan usia, terjadi penurunan kejadian kejang demam. Hal ini dapat dijelaskan dengan fakta bahwa kematangan dan myelinisasi pada otak meningkat secara progresif seiring dengan peningkatan usia. ${ }^{18}$

Hasil penelitian oleh Birua $\mathrm{dkk}^{20}$ juga mendukung penelitian ini dengan mendapatkan usia kejang demam pertama pada anak cenderung terjadi pada usia 1324 bulan. Birua $\mathrm{dkk}^{20}$ menyimpulkan bahwa dengan pertambahan usia, prevalensi kejang demam mengalami penurunan, dan penurunan terutama terjadi setelah usia 59 bulan. Penelitian tersebut menyimpulkan bahwa insiden kejang demam menurun secara nyata setelah usia empat tahun dan jarang terjadi pada anak dengan usia yang lebih tua dari 7 tahun dan kejadian puncak kejang demam berada pada usia sekitar 18 bulan. ${ }^{20} \mathrm{Jadi}$, usia berperan penting dalam menentukan seorang anak rentan mengalami kejang demam dan penurunan risiko kekambuhan kejang demam seiring dengan pertambahan usia. Walaupun mekanisme peningkatan kerentanan berdasarkan usia masih belum jelas, penelitian dengan model hewan menunjukkan adanya peningkatan eksitabilitas neuronal selama proses pematangan otak yang normal. ${ }^{20}$

Kategori klasifikasi kejang demam menunjukkan sebagian besar anak yang mengalami kejang demam pertama mengalami kejang demam sederhana $(69,5 \%)$, sementara sisanya mengalami kejang demam kompleks. Penentuan klasifikasi kejang demam sesuai dengan yang tertera dalam status rekam medis anak. Penentuan klasifikasi dimungkinkan berdasarkan anamnesis keluarga dan keadaan anak saat dirawat pada hari pertama kejang demam berupa sifat kejang demam (fokal/general), durasi kejang ( $<15$ menit / >15 menit), kejang berulang dalam 24 jam atau tidak. Hasil penelitian ini bertentangan dengan penelitian oleh Kakalang $\mathrm{dkk}^{13}$ yang mendapatkan kejang demam kompleks lebih banyak $(60,7 \%)$ dibanding kejang demam sederhana (39,3\%).

Berdasarkan ada atau tidaknya riwayat keluarga, penelitian ini menunjukkan sebagian besar sampel $(63,2 \%)$ tidak memiliki riwayat kejang demam pada keluarga. Hal ini berbeda dengan penelitian oleh Arifuddin $\mathrm{dkk}^{21}$ tahun 2016 yang melaporkan 60,8\% sampel anak dengan kejang demam memiliki riwayat kejang pada keluarga. Hal tersebut disebabkan karena adanya peranan mutasi gen yang diturunkan oleh keluarga yang memengaruhi eksitabilitas ion pada membran sel pada anak yang kemudian dapat memicu terjadinya kejang demam. ${ }^{21}$ Penelitian Chung $\mathrm{dkk}^{22}$ 
juga menjelaskan bahwa riwayat kejang pada keluarga memiliki peran yang menentukan kemungkinan kejang demam berulang pada anak dan kemungkinan berkembang menjadi kejang tanpa demam / epilepsi di masa depan. Perbedaan pada hasil penelitian ini dimungkinkan disebabkan adanya faktor lain yang lebih dominan yang memicu terjadinya kejang demam dibandingkan riwayat keluarga.

Penyebab yang mendasari kejang demam biasanya bersifat sekunder terhadap suatu episode demam. Hal ini terkait dengan infeksi virus ataupun infeksi bakteri yang berasal dari suatu proses ekstrakranial. ${ }^{23}$ Kondisi penyakit yang menyertai kejang demam sebagian besar disebabkan oleh infeksi saluran napas atas $(65,3 \%)$, diikuti gastroenteritis akut (14,7\%), infeksi saluran napas bawah (12,6\%), dan sebagian kecilnya disebabkan oleh demam tifoid, Sindrom Steven Johnson, dan morbili. Hal ini juga dijelaskan dalam penelitian Kavanagh $\mathrm{dkk}^{23}$ bahwa infeksi yang paling sering terjadi pada anak dengan kejang demam adalah infeksi virus pada traktur respiratorius bagian atas. Selain itu, infeksi lainnya yang umum terjadi pada masa kanak, seperti herpes dan infeksi virus lainnya, termasuk infeksi bakteri pada traktus respiratorius bagian atas dan bawah, serta gastroenteritis. ${ }^{23}$ Kejang demam terjadi pada anak pada masa perkembangan ketika ambang batas terhadap kejang masih tergolong rendah. ${ }^{24}$ Lebih lanjut, anak pada usia balita cenderung rentan mengalami berbagai infeksi yang sering terjadi pada masa kanak berupa infeksi saluran napas bagian atas, otitis media, dan infeksi virus lainnya. ${ }^{24}$ Berdasarkan studi pada hewan, adanya kombinasi faktorfaktor sebelumnya berperan dalam memengaruhi faktor pirogen endogen, seperti interleukin 1 beta, peningkatan eksitabilitas neuronal, menghubungkan terjadinya demam dengan aktivitas kejang. ${ }^{24}$ Penelitian pada anak belum menemukan kejelasan signifikansi peranan klinis dan patologis sitokin teraktivasi terhadap patogenesis dari kejang demam. ${ }^{24}$

Rata-rata lama rawat inap pasien kejang demam anak di RSUD Prof. Dr. M. A. Hanafiah pada tahun 2019 adalah 3,77 hari. Hal ini dimungkinkan bertujuan untuk observasi kemungkinan terjadinya kejang berulang dalam 24 jam untuk membedakan terjadinya kejang demam kompleks dengan kejang demam sederhana, dan untuk menurunkan demam serta memulihkan infeksi yang mendasari terjadinya kejang demam pada anak.

Mayoritas anak yang mengalami kejang demam memiliki status gizi yang baik. Hal ini didukung oleh penelitian oleh Kakalang $\mathrm{dkk}^{13}$ pada tahun 2016 yang mendapatkan 67,3\% anak dengan kejang demam memiliki status gizi yang normal / baik. Hasil berbeda didapat Hussain $\mathrm{dkk}^{14}$ bahwa mayoritas anak dengan kejang demam mengalami malnutrisi dengan persebaran 47 anak dengan kejang demam sederhana dan 17 anak kejang demam kompleks.

Kami tidak menemukan adanya hubungan status gizi terhadap usia kejang demam pertama pada anak. Penelitian ini didukung oleh studi yang dilakukan Oseni $\mathrm{dkk}^{25}$ pada tahun 2002 di Nigeria, dinyatakan bahwa kejang demam lebih umum terjadi pada anak dengan status gizi yang baik, dan tidak terdapat perbedaan pada uji beda yang dilakukan terhadap status gizi pada anak yang mengalami kejang demam. Penelitian ini juga belum mampu menjelaskan hubungan sebab akibat antara status gizi terhadap kejang demam. ${ }^{25}$ Hasil sejalan ditunjukkan oleh penelitian Hussain $\mathrm{dkk},{ }^{14}$ ditemukan tidak terdapat hubungan antara status gizi dengan kejadian kejang demam. ${ }^{14}$ Perbedaan hasil penelitian yang terjadi dapat disebabkan oleh variasi perbedaan ukuran, kecenderungan, etnis, dan kondisi sosioekonomi dari sampel kejang demam. ${ }^{14}$

Berdasarkan penelitian oleh Fuadi dkk, ${ }^{26}$ usia kejang demam pertama dipengaruhi oleh maturasi otak yang belum sempurna terutama pada usia kurang dari dua tahun. Pada penelitian tersebut didapatkan sebagian besar anak mengalami kejang demam pertama pada usia kurang dari dua tahun dan berdasarkan hasil uji statistik menyimpulkan bahwa anak dengan usia kurang dari dua tahun berisiko 3,4 kali lebih besar mengalami bangkitan kejang demam dibanding anak dengan usia lebih dari dua tahun. Anak dengan kejang demam pertama pada penelitian ini sebagian besar berada pada kelompok usia batita ( 12 bulan $\leq$ usia $<36$ bulan).

Maturasi otak yang belum sempurna pada usia kurang dari dua tahun, pada kondisi ini reseptor otak untuk neurotransmitter eksitatorik dan inhibitorik belum seimbang. ${ }^{26}$ Reseptor neurotransmitter eksitatorik asam glutamat baik ionotropik maupun metabotropik cenderung lebih aktif dibanding neurotransmitter inhibitorik GABA sehingga terjadi dominansi eksitasi pada otak yang belum matang. ${ }^{26}$ Juga, pada otak yang belum matang terdapat tingginya kadar CRH (corticotropin releasing hormone) yang merupakan neuropeptid eksitator yang berpotensi sebagai prokonvulsan sehingga dapat mendukung terjadinya bangkitan kejang pada anak ketika terjadi demam. ${ }^{26}$ 
Selain itu, usia kejang demam pertama dapat dipengaruhi oleh riwayat kejang demam pada keluarga. Penelitian yang dilakukan oleh Vebriasa $\mathrm{dkk}^{4}$ menyimpulkan bahwa kejang demam pertama pada anak terjadi pada usia yang lebih dini pada anak yang memiliki riwayat kejang pada keluarga, dengan nilai median 13,0 (11,0-18,0) bulan, dibandingkan anak tanpa riwayat kejang pada keluarga, dengan nilai median $17,0(11,0-29,0)$ bulan.

Hal ini menunjukkan terdapat kondisi yang bersifat multifaktorial yang dapat memicu terjadinya kejang demam pertama. Usia kejang demam pertama tidak dapat dinilai hanya dari status gizi saat anak mengalami kejang. Adanya status gizi dimungkinkan berperan menyertai kondisi anak dengan kejang demam, tetapi bukan sebagai faktor risiko utama yang memengaruhi secara langsung kejang demam pertama pada anak. Gizi anak tetap harus dijaga dengan baik untuk pertumbuhan, perkembangan, serta imunitas yang optimal, agar anak terhindar dari infeksi dan demam, sehingga dapat terhindar dari kejang demam.

Keterbatasan penelitian ini adalah terdapat beberapa data dan keterangan klinis yang kurang lengkap pada dokumen rekam medis sehingga tidak seluruh data pasien dapat digunakan.

\section{Kesimpulan}

Anak dengan kejang demam pertama paling banyak berada dalam kelompok usia batita dengan persentase $57,9 \%$. Sementara anak dengan kejang demam pertama memiliki kondisi gizi yang baik $(50,5 \%$ berdasarkan indeks IMT/U dan 51,6\% berdasarkan indeks BB/PB atau $\mathrm{BB} / \mathrm{TB})$. Hasil penelitian juga tidak mendapatkan hubungan bermakna antara status gizi dengan usia kejang demam pertama pada anak.

\section{Daftar pustaka}

1. Deng L, Gidding H, Macartney K, dkk. Postvaccination febrile seizure severity and outcome. Pediatrics 2019;143: e20182120. doi:10.1542/peds.2018-2120.

2. Leung A, Hon K, Leung T. Febrile seizures: an overview. Drugs in Context Peer Rev J 2018;7:2.

3. Patel N, Choudhary S MS. The association between iron deficiency anemia and febrile convulsion. J Med Sci Clin Res 2017;05:27478-81.
4. Vebriasa A, Herini ES, Triasih R. Hubungan antara riwayat kejang pada keluarga dengan tipe kejang demam dan usia saat kejang demam pertama. Sari Pediatri 2013;15:137-40.

5. Aswin A, Muhyi A, Hasanah N. Hubungan kadar hemoglobin dengan kejang demam pada anak yang disebabkan infeksi saluran pernapasan akut: studi kasus kontrol. Sari Pediatri 2019;20:270-5.

6. Fredlina J, Malik R. Hubungan status gizi terhadap anemia pada balita di Kelurahan Tomang Kecamatan Grogol Petamburan Jakarta Barat periode Januari 2015. Tarumanagara Med J 2018;1:110-5.

7. Pratama HA. Hubungan anemia defisiensi besi dengan status gizi pada balita di RSUD Kardinah [Internet]. Universitas Muhammadiyah Semarang; 2016. Diakses pada 26 Mei 2021. Didapat dari: http://lib.unimus.ac.id.

8. Kemkes RI. Riset kesehatan dasar (Riskesdas) 2018. Jakarta: Badan Penelitian dan Pengembangan Kesehatan Kementerian RI; 2018.

9. Rohimah E, Kustiyah L, Hernawati N. Pola konsumsi, status kesehatan dan hubungannya dengan status gizi dan perkembangan balita. Jurnal Gizi Pangan 2015;10:93-100.

10. Simbolon D. Pencegahan stunting melalui intervensi gizi spesifik pada ibu menyusui anak usia 0-24 bulan. Azizah N, penyunting. Bengkulu: Media Sahabat Cendekia; 2019.h.35-6.

11. Hairunis MN, Salimo H, Dewi YLR. Hubungan status gizi dan stimulasi tumbuh kembang dengan perkembangan balita. Sari Pediatri 2018;20:146-51.

12. El-Radhi AS. Clinical manual of fever in children. Edisi kedua. Orpington: Springer International Publishing; 2018.h.17992.

13. Kakalang JP, Masloman N, Manoppo JIC. Profil kejang demam di bagian ilmu kesehatan anak RSUP Prof. Dr . R. D. Kandou Manado. J e-Clinic 2016;4:1-6.

14. Hussain S, Tarar SH, Sabir MUD. Febrile seizures : demographic, clinical and etiological profile of children admitted with febrile seizures in a tertiary care hospital. J Pak Med Assoc 2015;65:1008-10.

15. Permatasari SPY, Gurnida DA, Chairulfatah A. Kemampuan alat deteksi dini risiko malnutrisi menurut American Society for Parenteral and Enteral Nutrition pada Anak 6-60 Bulan oleh Orang Tua. Sari Pediatri 2019;21:50-6.

16. Kemkes RI. Peraturan Menteri Kesehatan Republik Indonesia Nomor 2 Tahun 2020. Jakarta-:. Kemkes RI 2020.h.1-78.

17. Presto P, D'Souza P, Kopacz A, Hanson KA, Nagy L. Association between foramen size and febrile seizure status in the pediatric population: a two-center retrospective analysis. J Neurosci Rural Pract 2020;11:430-5.

18. Saheb SA. A study of febrile convulsions with a bacteremia incidence in a tertiary care teaching hospital in Andhra Pradesh. Int J Contemp Pediatr 2020;7:1885.

19. Laino D, Mencaroni E, Esposito S. Management of pediatric febrile seizures. Int J Environ Res Pub Health 2018;15:2232.

20. Birua S, Sarkar S, Bera A, Khan K. Clinico-demographic profile of febrile seizure and its association with iron deficiency. J Nepal Paediatr Soc 2019;39:72-8.

21. Arifuddin A. Analisis faktor risiko kejadian kejang demam. J 
Kesehat Tadulako 2016;2:60-72.

22. Chung S. Febrile seizures. Korean J Pediatrics 2014;57:384-95.

23. Kavanagh FA, Heaton PA, Cannon A, Paul SP. Recognition and management of febrile convulsions in children. Brit J Nurs 2018;27:1156-62.

24. Kumari L, Agrawal SD. Low zinc and iron status : a possible risk factor for febrile seizure. J Med Sci Clin Res 2019;07:256.

25. Oseni SBA, Esimai C, Oyedeji GA, Adelekan DA. Indices of nutritional status in children with febrile convulsion. Nutr Health 2002;16:143-4.

26. Fuadi F, Bahtera T, Wijayahadi N. Faktor risiko bangkitan kejang demam pada anak. Sari Pediatri 2010;12:142-9. 